interesting chapter in as much as it examines in detail ethical conflicts that might confront a counsellor in his or her practice. The discussion is based on the four principles of autonomy, beneficence, non-maleficence and justice. Although this chapter presents an in-depth examination of those ethical issues of which all those involved in counselling should be aware, it does not focus specifically on any particular issues that might be more relevant to a counsellor working in general practice. A discussion of the four principles with specific reference to a counsellor working as a member of a primary care team might have been useful in the context of the book's focus.

The final chapter looks to the future of counselling in general practice and at its funding, the involvement of Family Health Service Authorities, evaluation, standards and counsellors' training needs.

The message of the book is that counselling in general practice should be made more accessible to people in order that they may be appropriately enabled to deal with their problems and to live more resourcefully.

ROZY VAN MESDAG Counsellor, London

\section{Torture and its}

\section{consequences: current treatment approaches}

\author{
Edited by Metin Başoğlu, \\ Cambridge, Cambridge University \\ Press, 1992, 517 pages, £55.00.
}

Medical science has been slow to recognise the special needs of victims of torture but over the past decade or so there has been increasing awareness; papers have appeared and treatment and rehabilitation units have been set up round the world, some in countries which have experienced torture and some in countries which have accepted torture survivors as refugees. The effects of torture have often been equated with various other forms of trauma, such as those arising from war, natural or manmade disasters, and child or sexual abuse. While all of these conditions share many features, (for instance, child and sex abuse are deliberate acts degrading another and may be ongoing), each has its own specificity, and it would be wrong to lump them all together.

Should there then be a new specialty, dealing only with the diagnosis and treatment of torture victims? This question is put by the editor in the introduction to this book, bringing in the unpleasant-sounding neologism 'torturology'. Much space is given to consideration of post-traumatic stress disorder and most contributors agree that, although is is a valuable diagnosis, since it is recognised in major international classifications, and rightly demonstrates that very diverse causes of stress produce similar limited symptom patterns, it does not adequately cover the findings in torture survivors.

Since the editor and most of the contributors are psychiatrists or psychologists, there is a strong psychiatric slant in the book, many of the authors rightly pointing to the need for future research. One useful chapter on physical after-effects and chapters on the psycho-social consequences of torture and on its psycho-biological effects redress the balance somewhat. There are useful chapters on survivors of the holocaust and on the long-term fate of exprisoners of war. The predominant flavour of the book is of western experts writing from the safe perspective of their own country. This is helpfully offset by chapters from experts working in some of the countries which have experienced torture, namely, Argentina, South Africa, Pakistan and the Philippines. These, because the authors are able to convey their personal involvement, are the most compelling contributions of all. One aspect which seems to have been given less than its fair share of space is the psychosomatic effects of torture, and there is no mention at all of some, notably stress ulcer or hyperventilation. The origin of these effects needs to be detected but is often missed by non-specialists such as general practitioners or hospital doctors.

When it comes to treatment of the psychological after-effects, there is no consensus. Some contributors consider that mentioning the traumas of the past will trigger uncontrollable emotional distress, while the behaviourists regard recounting of events as an essential part of the therapy.

Altogether, this is a valuable discussion of current research and management of torture victims, of most use to those working in the field. The subject seems not to have been dealt with

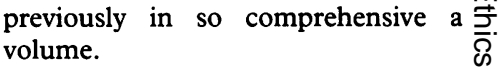
DUNCAN FORREST $\overrightarrow{\overrightarrow{\bar{\omega}}}$ Medical Foundation for the Care of Victims of Torture, London. Medical Group, Amnesty International, British Section.

Euthanasia and other medical decisions concerning the end of life

P J van der Maas, J J M van Delden, L Pijnenborg, Amsterdam, Elsevier, $1992,262+x v i i$ pages $\$ 160.50$.

This investigation was completed in 음 1991, and a variety of interpretations of its findings have been in circulation. $\mathcal{C}$ So it is useful now to have the full $\frac{\mathbb{D}}{0}$ account in English. This helps to $\underset{\mathbb{D}}{\vec{D}}$ temper some of the wilder claims and $\bar{z}$ counter-claims about the practice of $\underset{\mathbb{D}}{\mathbb{Q}}$ euthanasia in the Netherlands. The $\rightarrow$ book is based on interviews with ovf 400 Dutch physicians, who also cof laborated in a prospective study, a on data related to a sample of around 8,500 death certificates.

It found that in $1990,2,300$ or 1.8 per cent of all deaths in the $\frac{O}{\mathbb{D}}$ Netherlands could be classified as euthanasia ('purposeful acting to ter- $\overrightarrow{\overrightarrow{0}}$ minate life by someone other than the 3 person concerned upon the request of $\vec{F}$ the latter') and 400 or 0.3 per cent as assisted suicide. The lives of 1,000

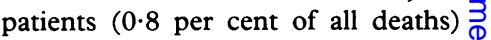
were terminated without explicit 0 request; and in the case of $22,5003$. others (17.5 per cent) pain and/or symptoms were alleviated, taking into $\frac{\mathrm{O}}{3}$ account a probable shortening of life. Very few patients in any of these $\frac{\text { 의 }}{\square}$ groups were likely to have survived for $D$ more than a further six months, and many had only days or hours to live. $\bar{N}$ Almost all significant shortening of life $\sigma$ was in the further category of $\mathrm{N}$ decisions to withhold or withdraw $N$ treatment, which could equally be $\sigma$ described as decisions not to prolong life by disproportionate means.

On initial reports of this investiga- $\mathbb{\mathscr { D }}$ tion, critics made much of the $1,000^{+}$ 'life terminating acts without request'. The book suggests that over half of the patients involved had earlier indicated $\stackrel{\mathbb{Q}}{\Omega}$ that they would have wanted their $\vec{\Phi}$ lives ended in these circumstances. $\frac{\sigma}{\sigma}$ Almost all of those whose wishes were not known were terminally ill, suffer- 
ing seriously, or no longer able to make their wishes known. Arguably, most of these decisions, and the 22,500 related to pain relief, would not have been very different had they been made in a British hospital or general practice. They might have been different in a British hospice: the vast majority of all patients whose lives were ended had cancer. The practical issues raised by this suggest the need for a more collaborative and less polarised discussion of these issues than is currently being conducted in Britain.

The investigation found that 62 per cent of Dutch doctors had performed euthanasia at some time, but also that two-thirds of requests were not acceded to. Patients whose lives were ended were more often in their $60 \mathrm{~s}$ than over 80 . This does not suggest the frail elderly being pressurised by overenthusiastic doctors, or support slippery slope arguments generally. A good defence against the latter, indeed, is the kind of willingness shown by Dutch doctors to have their decisions (including their failure to report many of them properly) scrutinised in the way this book reports. But in the end, no safeguards, under any legal system, can substitute for the integrity of those taking these decisions. The real issues in the euthanasia debate are those which have to be tackled in the arena of medical education in ethics, communication and the relief of pain and suffering.

KENNETH M BOYD Scottish Director and Research Director,

Institute of Medical Ethics, 1 Doune Terrace, Edinburgh EH3 6DY

\section{Ethics, reproduction and genetic control}

Edited by Ruth F Chadwick, London, Routledge, revised edition, 1992, 200 pages, $£ 10.99$.

Published by Croom Helm Ltd in 1987, and in paperback form by
Routledge in 1990, this book has already been reviewed in the journal (by A J Burfoot, the June issue 1991, page 105). Since the first edition there have been many changes in reproductive technology and medical genetics. Therefore readers might expect the new edition to examine those developments in the context of Ruth Chadwick's field, social ethics. They will be disappointed. This edition has the same ten chapters, each unrevised and with references no later than 1986. There is a revised preface by $\mathrm{Dr}$ Chadwick of 14 pages (with 51 references up to 1992), but that is too short to update in vitro fertilisation, women's interests, egg donation, developments in genetics and gene therapy, all of which are fields which have undergone marked change.

Which changes should have been discussed? Surely the implementation of the Human Fertilisation and Embryo Act, with the regular visiting of IVF centres by HFEA sub-committees; or the role for independent counsellors, which is enshrined in the HFEA legislation. In IVF itself, technological advances (including sub-zonal injection methods) have led to successful pregnancies even in couples who were previously considered to be untreatable. Research into folic acid therapy for the fragile $\mathrm{X}$ syndrome has now run for over a decade - Jerome Lejeune's emotive paper needs updating; the reader should be told that folate has no effect on IQ but significantly improves behaviour. What has happened in Singapore? The government's eugenic programme, laid out in Chan's paper, was so stark and frightening that eight years on, we deserve a follow-up.

A further difficulty is that the essays on which this book is based were chosen provocatively, and are by authors who, individually, or as a group, do not reflect a balance of viewpoints, or even completeness in one particular country. For example, the chapters on 'Marriage and the family' (by the Board of Social Responsibility of the General Synod of the Church of England), on 'IVF and the law' (by Sir David Napley), on 'In vitro fertilisation and the Warnock Report' (by Professor R M
Hare), and much of the two chapters by Chadwick herself, 'Having children' and 'The perfect baby', deal with the UK experience. Where though is the UK clinical geneticist or reproductive clinician/scientist? Internationally renowned units are not far distant from Dr Chadwick's own base.

To a medical geneticist even the title is disturbing. 'Genetic control' is not what we seek to do when we see troubled couples or families in the genetic clinic. Geneticists hope to relieve distress (in most instances) by providing accurate, up-to-date and relevant information, as well as by listing the available options. When individuals are empowered to exercise their right to choose for themselves, the result is not eugenic but the reverse. This is because such personal choices will increase variation in the gene pool - a point not understood by Dr Chadwick (in her chapter 'The perfect baby') or by Amitai Etzioni or Germaine Greer, both of whom are cited. The unreferenced chapter by Robert Sinsheimer, 'The prospect of designed genetic change', begins with a confused description of gene therapy for diabetes which implies wrongly that transduction of beta cells in the Islets of Langerhans with an exogenous pro-insulin gene would also influence the germ cells. Sinsheimer ends like Hamlet with unclear ramblings so divorced from medical genetics and informed choice that I know not whether to believe him and shudder or to assume untruthful sarcasm. Those who wish to learn about gene therapy should skip Sinsheimer and read French Anderson (chapter 8) instead.

Those comments aside this book is an attempt to redress the balance between the technology and the social science. The missing link in that pursuit is a lack of the genetic counselling perspective. There are medical genetic teams that acknowledge the value of social scientists. In a proper second edition of Chadwick's book space might be found to reciprocate.

SANDY RAEBURN Professor of Clinical Genetics, Nottingham 